\title{
FAKTOR - FAKTOR YANG BERHUBUNGAN DENGAN KEJADIAN RUPTUR PERINEUM PADA IBU BERSALIN
}

\author{
Nurulicha*
}

\begin{abstract}
ABSTRAK
Perdarahan post partum menjadi penyebab utama 40\% kematian ibu di Indonesia. Robekan Jalan lahir merupakan penyebab kedua tersering dari perdarahan pasca persalinan setelah atonia uteri. Ruptur perineum merupakan perlukaan jalan lahir yang terjadi pada saat kelahiran bayi baik menggunakan alat maupun tidak menggunakan alat. Tujuan penelitian ini adalah untuk mengetahui Faktor-faktor yang berhubungan dengan kejadian ruptur perinium pada ibu bersalin di Bidan Praktek Swasta Desa Mekarsari Kabupaten Bogor tahun 2015. Penelitian ini dilakukan dengan metode penelitian analitik dengan pendekatan cross sectional, analisa data dengan uji Chi-square. Data yang dikumpulkan berupa data sekunder yang di dapat dari rekam medik pasien. Sampel yang diambil berjumlah 86 orang, teknik total sampling. Analisa yang digunakan adalah univariat dan bivariat. Hasil penelitian tidak ada hubungan yang signifikan antara faktor paritas dengan kejadian rupur perineum, dari 86 responden 58 orang (67\%) ibu dengan multipara/grande multipara dengan Pvalue $=0,058$, sedangkan terdapat hubungan yang signifikan antara jarak kehamilan dengan ruptur perinem, dari 86 responden 50 orang (58\%) pada jarak kehamilan $\geq 2$ tahun dengan Pvalue=0,038,OR=1,023, terdapat hubungan yang signifikan antara berat badan bayi dengan ruptur perineum, dari 86 responden 69 orang $(80 \%)$ ibu bersalin dengan berat badan bayi 2500-4000 dengan Pvalue $=0{ }^{\prime} 028, O R=1,144$, terdapat hubungan yang signifikan antara umur ibu dengan ruptur perineum, dari 86 responden 73 orang (85\%) melahirkan pada kelompok umur 20-35 tahun dengan Pvalue $=0,046, O R=0,046$ dan terdapat hubungan yang signifikan antara episiotomi dengan ruptur perineum dari 86 responden 70 orang (81\%) tidak dilakukan episiotomi dengan Pvalue=0,034, OR=1,14ldengan kejadian ruptur perineum.
\end{abstract}

Kata kunci : Ruptur perinium, paritas, jarak kehamilan, berat badan bayi, umur, episiotomy

\begin{abstract}
Postpartum hemorrhage is a major cause $40 \%$ of maternal deaths in Indonesia. Rips Road birth is the second most common cause of postpartum hemorrhage after an atonic. Rupture of the perineum is the birth canal injury that occurred at the time of birth either using or not using a tool. The purpose of this study was to determine the factors associated with rupture perinium on maternity midwife mother Private Practice Bogor Regency Village Mekarsari 2015. Penelitian year was conducted by the method of analytic research with cross sectional data analysis with Chi-square test using SPSS 22.Data collected in the form of secondary data obtained from patient records. Samples were taken totaling 86 people, total sampling technique. The analysis used is univariate and bivariate. The results of the study there was no significant relationship between the factors of parity with incident rupur perineum, of 86 respondents 58 people $(67 \%)$ of mothers with multiparous/grande multipara with pvalue $=0.058$, whereas there is a significant correlation between the distance pregnancy with rupture perinem, of 86 respondents 50 people (58\%) at a distance of pregnancy $\geq 2$ years with pvalue $=0.038, \mathrm{OR}=1.023$, there is a significant relationship between infant weight with rupture perineum, 69 of 86 respondents $(80 \%)$ of mothers with a birth weight babies $2500-4000$ with pvalue $=0^{\prime} 028, \mathrm{OR}=1.144$, there is a significant relationship between mother's age at rupture perineum, 73 of 86 respondents $(85 \%)$ gave birth to the age group of 20-35 years with pvalue $=0.046, \mathrm{OR}=0.046$ and contained a significant association between episiotomy to perineal rupture of 86 respondents 70 people $(81 \%)$ did not do an episiotomy with pvalue $=0.034$, OR $=1,141$ dengan rupture perineum.
\end{abstract}

Keywords: Ruptured perinium, parity, spacing of pregnancy, the baby's weight, age, episiotomy

\footnotetext{
* Staf Pengajar AKBID Bhakti Indonesia Bogor
} 


\section{PENDAHULUAN}

Persalinan merupakan suatu proses pengeluaran hasil konsepsi yang dapat hidup, dari dalam uterus melalui vagina ke dunia luar. Persalinan terdiri dari kala I,kala II, kala III dan kala IV. Persalinan dan kelahiran merupakan kejadian fisiologis yang normal dalam kehidupan. Tetapi tidak semua persalinan fisiologis, kadang persalinan bisa menjadi patologis, dan bisa berakibat terhadap kematian ibu dan bayi. ${ }^{1}$

Menurut Word Healt Organization (WHO) memperkirakan ada 500.000 kematian ibu melahirkan di seluruh dunia setiap tahun, 99 persen terjadi di negara berkembang. Dan salah satu negara berkembang adalah indonesia. Hasil Survei Demografi Kesehatan Indonesia (SDKI) menyebutkan bahwa pada tahun 2012, kasus kematian melonjak tajam, dimana AKI mencapai 359 per 100.000 kelahiran hidup, meningkat sekitar 57\% bila dibandingkan dengan tahun 2007 yang hanya sebesar 248 per 100.000 kelahiran hidup. Tahun 2015 Angka kematian ibu di jawa barat tercatat 823 orang. Dari angka tersebut Jawa Barat menjadi penyumbang 50\% jumlah kematian ibu. Data dari Dinas Kesehatan Jawa Barat tahun 2014 menyebutkan dalam per10.000 kelahiran, jumlah AKI di kabupaten Bogor mencapai 71 jiwa. Dari data tersebut kabupaten Bogor masih menjadi penyumbang tertinggi angka kematian ibu di Jawa Barat. Penyebab utama kematian ibu di negara berkembang adalah faktor obstetri langsung, yaitu perdarahan postpartum, infeksi dan eklamsi. Kelainan perdarahan post partum yang terjadi pada kala ketiga (kala uri) yaitu retensio placenta, inversio uteri, dan perdarahan robekan jalan lahir. Perdarahan postpartum adalah perdarahan yang terjadi dalam waktu 24 jam pertama. ${ }^{2}$

Perdarahan post partum menjadi penyebab utama $40 \%$ kematian ibu di Indonesia. Robekan Jalan lahir merupakan penyebab kedua tersering dari perdarahan pasca persalinan setelah atonia uteri. Robekan juga dapat terjadi bersamaan dengan atonia uteri. Perdarahan pasca persalinan dengan uterus yang berkontraksi baik biasanya disebabkan karena robekan serviks atau vagina. Robekan perineum terjadi pada hampir persalinan pertama dan tidak jarang juga pada persalinan berikutnya. $^{3}$

Ruptur perineum merupakan perlukaan jalan lahir yang terjadi pada saat kelahiran bayi baik menggunakan alat maupun tidak menggunakan alat. Faktor-faktor yang menyebabkan terjadinya ruptur perineum adalah paritas, jarak kelahiran, berat badan bayi, pimpinan persalinan tidak sebagaimana mestinya, umur, ekstraksi cunam, ekstraksi vakum, trauma alat dan episiotomi. ${ }^{4}$

Di seluruh dunia pada tahun 2009 terjadi 2,7 juta kasus ruptur perinium pada ibu bersalin. Di Asia masalah robekan perineum cukup banyak dalam masyarakat, 50\% dari kejadian robekan perinium di dunia terjadi di Asia.Ruptur perineum dialami oleh 85\% wanita yang melahirkan pervaginam. Prevelensi ibu bersalin yang mengalami robekan perineum di Indonesia pada golongan umur 25-30 tahun yaitu 24\% sedang pada ibu bersalin usia 32-39 tahun sebesar 62\%. Ruptur perinium perlu mendapatkan perhatian karena dapat menyebabkan disfungsi organ reproduksi wanita, sebagai sumber perdarahan, dan sumber atau jalan keluar masuknya infeksi, yang kemudian dapat menyebabkan kematian karena perdarahan atau sepsis. ${ }^{5}$

Berdasarkan studi pendahuluan yang dilakukan di Bidan Praktek Swasta didapatkan adanya peningkatan angka kejadian ruptur perineum pada ibu bersalin selama dua tahun berturut-turut yaitu tahun 2013 sebanyak 41 orang dari 63 persalinan normal, dan yang tidak mengalami ruptur perineum sebanyak 22 orang, dan pada tahun 2014 sebanyak 68 orang dari 88 persalinan normal dan yang tidak mengalami ruptur sebanyak 20 orang. Pada tahun 2015 yang mengalami ruptur perinuim sebanyak 70 orang dari 86 persalinan normal, dan yang 16 tidak mengalami ruptur perinium. Penelitian ini bertujuan untuk mengetahui Untuk mengetahui Faktor-faktor yang berhubungan dengan kejadian ruptur perinium pada ibu bersalin di Bidan Praktek Swasta Desa Mekarsari Kabupaten Bogor tahun 2015.

\section{METODE PENELITIAN}

Rancangan penelitian yang digunakan adalah bersifat analitik dengan pendekatan cross sectional. Penelitian ini merupakan data sekunder dimana variabel bebasnya adalah paritas, jarak kelahiran, berat badan bayi, umur dan episiotomi sedangkan variabel terikatnya adalah ibu bersalin 
dengan ruptur perineum. Populasi dalam penelitian ini adalah seluruh ibu bersalin berjumlah 86 orang di Bidan Praktek Swasta Desa Mekarsari tahun 2015. Teknik pengambilan sampel menggunakan total sampling, instrument dan alat yang digunakan adalah check list. Analisa univariat dilakukan terhadap tiap variabel dari hasil penelitian. Analisa bivariat adalah analisa yang digunakan untuk mencari/mengetahui adanya hubungan antara dua variabel, yaitu variabel independen dan dependent. Uji statistik yang digunakan adalah Chi-square karena variabel independen dan dependen merupakan data kategori. Dalam uji ini ditentukan tingkat kemaknaan (nilai alpha sebesar 0,05).

\section{HASIL PENELITIAN \\ Distribusi Frekuensi}

Hasil penelitian distribusi frekuensi menunjukkan bahwa dari 86 responden yang diteliti, mayoritas ibu bersalin dengan kejadian ruptur perinium sebanyak 70 orang (81\%) dan ibu bersalin yang tidak mengalami kejadian ruptur perinium sebanyak 16 orang (19\%), dari 86 responden 28 orang $(33 \%)$ paritas ibu pada primipara sedangkan 58 orang $(67 \%)$ paritas ibu multipara, bahwa dari 86 responden 36 orang $(42 \%)$ terdapat pada jarak kehamilan $<2$ tahun, sedangkan 50 orang (58\%) pada jarak kehamilan $\geq 2$ tahun, bahwa dari 86 responden 17 orang $(20 \%)$ ibu bersalin melahirkan dengan berat badan bayi > 4000 gram dan 69 orang (80\%) ibu bersalin melahirkan dengan berat badan bayi 2500-4000 gram, bahwa dari 86 responden 13 orang (15\%) melahirkan pada kelompok umur $<20$ tahun, $>35$ tahun, dan 73 orang $(85 \%)$ melahirkan pada kelompok umur 20-35 tahun, dan dari 86 responden kejadian ruptur perineum pada ibu bersalin disebabkan karena dilakukan episiotomi sebanyak 16 orang (19\%), dan yang tidak dilakukan episiotomi sebanyak 70 orang $(81 \%)$.

\section{Hubungan Faktor Paritas dengan Kejadian Ruptur Perineum}

Tabel 1. Hubungan faktor Paritas dengan kejadian ruptur perineum pada ibu bersalin

\begin{tabular}{|c|c|c|c|c|c|c|c|c|c|}
\hline \multirow[t]{2}{*}{ No } & \multirow{2}{*}{$\begin{array}{c}\text { Kejadian Ruptur } \\
\text { Variabel } \\
\text { Paritas }\end{array}$} & \multicolumn{4}{|c|}{ Kejadian Ruptur Perinium } & \multirow{2}{*}{ Jumlah } & \multirow{2}{*}{ Total } & \multirow{2}{*}{$\begin{array}{c}\text { P } \\
\text { Value }\end{array}$} & \multirow[t]{2}{*}{ OR } \\
\hline & & $\mathrm{Ya}$ & $\%$ & Tidak & $\%$ & & & & \\
\hline 1 & Primipara & 26 & 92,9 & 2 & 7,1 & 28 & 100 & \multirow{3}{*}{0,058} & \multirow{3}{*}{$1,025-1,462$} \\
\hline 2 & $\begin{array}{c}\text { Multipara/Grande } \\
\text { multipara }\end{array}$ & 44 & 75,9 & 14 & 24,1 & 58 & 100 & & \\
\hline & Total & 70 & 81,4 & 16 & 18,6 & 86 & 100 & & \\
\hline
\end{tabular}

Berdasarkan tabel 1 diketahui dari 28 ibu bersalin dengan paritas primipara mengalami kejadian ruptur perineum sebanyak 26 orang $(92,9 \%)$ dan yang tidak ruptur sebanyak 2 orang $(7,1 \%)$ sedangkan 58 ibu bersalin dengan paritas multipara 44 orang $(75,9 \%)$ mengalami kejadian ruptur perineum, dan yang tidak ruptur 14 orang $(24,1 \%)$. Berdasarkan uji statistik dengan chisquare didapatkan $\mathrm{P}$ value $=0,058 \alpha \geq 0,05$ artinya Ho gagal ditolak berarti tidak ada hubungan yang bermakna antara paritas dengan kejadian ruptur perineum pada ibu bersalin.

\section{Hubungan faktor jarak kehamilan dengan kejadian ruptur perineum}

Tabel 2. Hubungan faktor jarak kehamilan dengan kejadian ruptur perineum pada ibu bersalin

\begin{tabular}{|c|c|c|c|c|c|c|c|c|c|}
\hline \multirow[t]{2}{*}{$\overline{\mathrm{No}}$} & \multirow{2}{*}{$\begin{array}{c}\text { Variabel } \\
\text { Jarak Kehamilan }\end{array}$} & \multicolumn{4}{|c|}{ Kejadian Ruptur Perinium } & \multirow{2}{*}{ Jumlah } & \multirow{2}{*}{ Total } & \multirow{2}{*}{$\begin{array}{c}\mathrm{P} \\
\text { Value }\end{array}$} & \multirow[t]{2}{*}{ OR } \\
\hline & & $\mathrm{Ya}$ & $\%$ & Tidak & $\%$ & & & & \\
\hline 1 & $<2$ tahun & 33 & 91,7 & 3 & 8,3 & 36 & 100 & \multirow{3}{*}{0,038} & \multirow{3}{*}{$1,023-1,500$} \\
\hline 2 & $\geq 2$ tahun & 37 & 74 & 13 & 26 & 50 & 100 & & \\
\hline & Total & 70 & 81,4 & 16 & 18,6 & 86 & 100 & & \\
\hline
\end{tabular}


Berdasarkan tabel 2 diketahui dari 36 ibu bersalin dengan jarak kehamilan $<2$ tahun mengalami kejadian ruptur perinium sebanyak 33 orang $(91,7 \%)$ dan yang tidak ruptur sebanyak 3 orang $(8,3 \%)$, sedangkan dari 50 ibu bersalin dengan jarak kehamilan $\geq 2$ tahun sebanyak 37 orang (74\%) mengalami kejadian ruptur perinium, dan yang tidak ruptur 13 orang (26\%). Berdasarkan uji statistik dengan chi-square didapatkan $\mathrm{P}$ value $=0,038 \alpha \leq 0,05$ artinya ada hubungan yang bermakna antara jarak kehamilan dengan kejadian ruptur perinium pada ibu bersalin. Berdasarkan analisa keeratan hubungan 2 variabel didapatkan nilai $\mathrm{OR}=1,023$, artinya ibu bersalin dengan jarak kehamilan $<2$ tahun memiliki peluang 1,023 kali untuk mengalami kejadian ruptur perinium dibanding ibu bersalin dengan jarak kehamilan $\geq 2$ tahun.

\section{Hubungan faktor berat badan bayi dengan kejadian ruptur perinium}

Tabel 3. Hubungan factor Berat Badan Bayi dengan kejadian rupture perineum pada ibu bersalin

\begin{tabular}{|c|c|c|c|c|c|c|c|c|c|}
\hline \multirow[t]{2}{*}{ No } & \multirow{2}{*}{$\begin{array}{c}\text { Variabel Berat } \\
\text { Badan Bayi }\end{array}$} & \multicolumn{4}{|c|}{ Kejadian Ruptur Perinium } & \multirow{2}{*}{ Total } & \multirow{2}{*}{$\%$} & \multirow{2}{*}{$\begin{array}{c}\mathrm{P} \\
\text { Value }\end{array}$} & \multirow{2}{*}{ OR } \\
\hline & & $\mathrm{Ya}$ & $\%$ & Tidak & $\%$ & & & & \\
\hline 1 & $>4000$ gram & 17 & 100 & 0 & 0 & 17 & 100 & \multirow{3}{*}{$-0,028$} & \multirow{3}{*}{$1,144-1,482$} \\
\hline 2 & 2500-4000 gram & 53 & 76,8 & 16 & 23,2 & 69 & 100 & & \\
\hline & Total & 70 & 81,4 & 16 & 18,6 & 86 & 100 & & \\
\hline
\end{tabular}

Berdasarkan tabel 3 diketahui dari 17 ibu bersalin dengan berat badan bayi lebih dari 4000 gram mengalami kerjadian ruptur perinium sebanyak 17 orang $(100 \%)$ dan yang tidak ruptur sebanyak 0 orang (0\%) sedangkan dari 69 ibu bersalin dengan berat badan bayi 2500-4000 gram sebanyak 53 orang $(76,8 \%)$ mengalami kejadian ruptur perinium, dan yang tidak ruptur 16 orang $(23,2 \%)$. Berdasarkan uji statistik dengan chi-square didapatkan $\mathrm{P}$ value $=0,028 \alpha \leq 0,05$ artinya ada hubungan yang bermakna antara berat badan bayi dengan kejadian ruptur perinium pada ibu bersalin. Berdasarkan analisa keeratan hubungan 2 variabel didapatkan nilai $\mathrm{OR}=1,144$, artinya ibu bersalin dengan berat badan bayi > 4000 gram memiliki peluang 1,144 kali untuk mengalami kejadian ruptur perinium dibanding ibu bersalin dengan berat badan bayi 2500 - 4000 gram.

\section{Hubungan Faktor Umur Ibu dengan Kejadian Ruptur Perineum}

Tabel 4. Hubungan faktor Umur Ibu dengan kejadian ruptur perineum pada ibu bersalin

\begin{tabular}{|c|c|c|c|c|c|c|c|c|c|}
\hline \multirow{2}{*}{ No } & \multirow{2}{*}{$\begin{array}{c}\text { Variabel } \\
\text { Umur Ibu }\end{array}$} & \multicolumn{4}{|c|}{ Kejadian Ruptur Perinium } & \multirow{2}{*}{ Total } & \multirow{2}{*}{$\%$} & \multirow{2}{*}{$\begin{array}{c}\mathrm{P} \\
\text { Value }\end{array}$} & \multirow[t]{2}{*}{ OR } \\
\hline & & Ya & $\%$ & Tidak & $\%$ & & & & \\
\hline 1 & $<20$ tahun, $>35$ tahun & 8 & 61,5 & 5 & 38,5 & 13 & 100 & \multirow{3}{*}{0,046} & \multirow{3}{*}{$0,466-1,126$} \\
\hline 2 & 20 tahun -35 tahun & 52 & 84,9 & 11 & 15,1 & 73 & 100 & & \\
\hline & Total & 70 & 81,4 & 16 & 18,6 & 86 & 100 & & \\
\hline
\end{tabular}

Berdasarkan tabel 4 diketahui dari 13 ibu bersalin dengan kelompok umur $<20$ tahun, $>35$ tahun mengalami kerjadian ruptur perinium sebanyak 8 orang $(61,5 \%)$ dan yang tidak ruptur sebanyak 5 orang $(38,5 \%)$ sedangkan dari 73 ibu bersalin dengan kelompok umur 20-35 tahun sebanyak 62 orang $(84,9 \%)$ mengalami kejadian ruptur perinium, dan yang tidak ruptur 11 orang $(15,1 \%)$. Berdasarkan uji statistik dengan chi-square didapatkan P value $=0,046 \alpha \leq 0,05$ artinya ada hubungan yang bermakna antara umur ibu dengan kejadian ruptur perinium pada ibu bersalin. Berdasarkan analisa keeratan hubungan 2 variabel didapatkan nilai $\mathrm{OR}=0,466$, artinya ibu bersalin dengan umur $<20$ tahun, $>35$ tahun memiliki peluang 0,466 kali untuk mengalami kejadian ruptur perinium dibanding ibu bersalin dengan umur 20-35 tahun.

\section{PEMBAHASAN}

\section{Hubungan Paritas Dengan Kejadian Ruptur Perinium}

Berdasarkan uji statistik dengan chi-square didapatkan $\mathrm{P}$ value $=0,058 \alpha \geq 0,05$ berarti tidak ada hubungan yang signifikan antara paritas dengan kejadian ruptur perinium pada ibu bersalin.Hal ini tidak 
sesuai dengan teori yang dikemukakan oleh Winknjosastro (2011), bahwa paritas merupakan salah satu faktor yang dapat mempengaruhi terjadinya ruptur perinium. Robekan perinium terjadi pada hampir semua primipara, sementara pada multipara dan grandemultipara jarang terjadi, hal ini disebabkan karena multipara dan grandemultipara elastisitas perinium pada umumnya elastis, sehingga resiko terjadinya ruptur perinium kecil jika dibandingkan dengan primipara.

Hasil penelitian ini juga tidak sesuai dengan penelitain yang dilakukan oleh Handiyah Vera Siska Lailatari yang berjudul Hubungan Paritas dengan Kejadian Ruptur Perinium Pada Ibu bersalin di RSUD DR. Wahidin Sudirohusodo Mojokerto Tahun 2013 bahwa ada hubungan paritas dengan kejadian ruptur perinium dengan $\mathrm{P}$ value $=0,000$. Sebagian besar responden adalah primipara yaitu sebanyak $36,1 \%$.Kejadian ruptur perinium menunjukan bahwa sebagian besar mengalami kejadian rupture 74,3\%.

\section{Hubungan Jarak Kehamilan dengan Kejadian Ruptur Perinium}

Berdasarkan analisa keeratan hubungan 2 variabel didapatkan nilai $\mathrm{OR}=1,023$, artinya ibu bersalin dengan jarak kehamilan $<2$ tahun memiliki peluang 1,023 kali untuk mengalami kejadian ruptur perinium dibanding ibu bersalin dengan jarak kehamilan $\geq 2$ tahun. Hal ini sesuai dengan teori yang menyatakan ibu yang mempunyai jarak kehamilan kurang dari 2 tahun rata-rata mengalami robekan jalan lahir. Robekan jalan lahir disebabkan karena ibu melahirkan teralu cepat sehingga proses pemulihan jalan lahir belum sempurna dan robekan perinium dapat terjadi pada saat melahirkan lagi. Jarak kelahiran 2-3 tahun merupakan jarak kelahiran yang lebih aman bagi ibu dan janin. Begitu juga dengan keadaan jalan lahir yang mungkin pada persalinan terdahulu mengalami robekan perineum derajat tiga atau empat, sehingga proses pemulihan belum sempurna dan robekan perineum dapat terjadi. ${ }^{6}$

Hal ini sesuai dengan hasil penelitian Rosdiana yang berjudul Faktor- faktor Yang Mempengaruhi Terjadinya Ruptur Perinium Pada Ibu Bersalin Normal di PONED Darul Imarah Aceh Besar tahun 2013, didapatkan hasil ada pengaruh jarak kehamilan terhadap kejadian ruptur perinium pada ibu bersalin normal (P value=0,010). Hasil penelitian menunjukan ibu yang berada pada kategori jarak kehamilan < 2 tahun lebih besar presentasenya mengalami ruptur perinium $(52,0 \%)$ dibandingkan dengan ibu yang mempunyai jarak kehamilan $\geq 2$ tahun $(16,1 \%)$.

\section{Hubungan Berat Badan Bayi dengan Kejadian Ruptur Perinium}

Berdasarkan uji statistik dengan chi-square didapatkan $\mathrm{P}$ value $=0,028 \alpha \leq 0,05$ artinya ada hubungan yang bermakna antara berat badan bayi dengan kejadian ruptur perinium pada ibu bersalin. Berdasarkan analisa keeratan hubungan 2 variabel didapatkan nilai $\mathrm{OR}=1,144$, artinya ibu bersalin dengan berat badan bayi > 4000 gram memiliki peluang 1,144 kali untuk mengalami kejadian ruptur perinium dibanding ibu bersalin dengan berat badan bayi 2500 - 4000 gram.

Hal ini sesuai dengan teori Mochtar (2008) Pada janin yang mempunyai berat lebih dari 4000 gram memiliki kesukaran yang ditimbulkan dalam persalinan adalah karena besarnya kepala atau besarnya bahu. Bagian paling keras dan besar dari janin adalah kepala, sehingga besarnya kepala janin mempengaruhi berat badan janin. Oleh karena itu sebagian ukuran kepala digunakan berat badan ( BB) janin. Kepala janin besar dan janin besar dapat menyebabkan laserasi perineum.

Hal ini juga sesuai dengan hasil penelitiaan Anita Lontaan yang berjudul Faktor-faktor yang berhubungan dengan robekan jalan lahir pada ibu bersalin di RS Jiwa Prof. Dr. V.L. Ratumbuysang Manado tahun 2013, menyatakan bahwa ada hubungan berat bayi lahir dengan robekan jalan lahir dengan nilai $\mathrm{P}$ value $=0,000$, didapatkan hasil berat badan bayi lahir dengan robekan jalan lahir derajat satu sebanyak 26 $(38,2 \%)$.

\section{Hubungan Faktor Umur Ibu dengan Kejadian Ruptur Perinium}

Berdasarkan uji statistik dengan chi-square didapatkan $\mathrm{P}$ value $=0,046 \alpha \leq 0,05$ artinya ada hubungan yang bermakna antara umur ibu dengan kejadian ruptur perinium pada ibu bersalin. Berdasarkan analisa keeratan hubungan 2 variabel didapatkan nilai $\mathrm{OR}=0,466$, artinya ibu bersalin dengan umur $<20$ tahun, > 35 tahun memiliki peluang 0,466 kali untuk mengalami kejadian ruptur perinium dibanding ibu bersalin dengan umur 20-35 tahun. Umur ibu juga dapat menjadi faktor penyebab ruptur perinium. Pada usia dibawah 20 tahun, fungsi reproduksi seorang wanita belum berkembang dengan sempurna. Sedangkan pada usia di atas 35 tahun fungsi reproduksi seorang wanita sudah mengalami penurunan dibandingkan fungsi reproduksi normal sehingga kemungkinan untuk terjadinya komplikasi pasca persalinan seperti ruptur perinium akan lebih besar. ${ }^{6} \mathrm{Hal}$ ini sesuai dengan penelitian lain yang dilakukan oleh Saras Ayu Mustika dan Evi Sri Suryani, yang berjudul Hubungan Umur Ibu Dan Lama Persalinan Dengan Kejadian Ruptur 
Perineum Pada Ibu Primipara Di BPS Ny. Ida Farida Desa Pancasan Kecamatan Ajibarang Kabupaten Banyumas tahun 2010 menyatakan Hasil uji statistik diperoleh nilai korelasi Chi Square dengan P value $0,022<\alpha 0,05$, hal ini menunjukan ada hubungan antara umur ibu bersalin dengan kejadian ruptur perineum. Responden yang tidak mengalami kejadian ruptur perineum cenderung berumur tidak beresiko (20-35 tahun) yaitu sebanyak 16 orang $(80.0 \%)$ sedangkan responden yang mengalami ruptur perineum adalah responden yang berumur resiko tinggi sebanyak 11 orang (55.0\%). Pada umur $<20$ tahun, organ-organ reproduksi belum berfungsi dengan sempurna, sehingga bila terjadi kehamilan dan persalinan akan lebih mudah mengalami komplikasi. Selain itu, kekuatan otot-otot perineum dan otot-otot perut belum bekerja secara optimal, sehingga sering terjadi persalinan lama atau macet yang memerlukan tindakan. Faktor risiko untuk persalinan sulit pada ibu yang belum pernah melahirkan pada kelompok umur ibu dibawah 20 tahun dan pada kelompok umur di atas 35 tahun adalah 3 kali lebih tinggi dari kelompok umur reproduksi sehat (20-35 tahun) .

\section{SIMPULAN}

1. Tidak terdapat adanya hubungan yang signifikan antara paritas dengan kejadian ruptur perineum pada ibu bersalin, hal ini dapat dilihat dari hasil penelitian yang menunjukan bahwa $\mathrm{P}$ value lebih besar dari pada $\alpha$. Diketahui nilai P value $=0,058 \alpha \geq 0,05$.

2. Terdapat hubungan yang signifikan antara jarak kehamilan dengan kejadian ruptur perineum pada ibu bersalin, hal ini dapat dilihat dari hasil penelitian yang menunjukan bahwa $\mathrm{P}$ value lebih kecil dari pada $\alpha$. Diketahui nilai P value $=0,038 \alpha \leq 0,05$.

3. Terdapat hubungan yang signifikan antara berat badan janin dengan kejadian ruptur perineum pada ibu bersalin, hal ini dapat dilihat dari hasil penelitian yang menunjukan bahwa $\mathrm{P}$ value lebih kecil dari pada $\alpha$. Diketahui nilai P value $=0,028 \alpha \leq 0,05$.

4. Terdapat hubungan yang signifikan antara umur ibu dengan kejadian ruptur perineum pada ibu bersalin, hal ini dapat dilihat dari hasil penelitian yang menunjukan bahwa $\mathrm{P}$ value lebih kecil dari pada $\alpha$. Diketahui nilai P value $=0,046 \alpha \leq 0,05$.

\section{SARAN}

Diharapkan bagi bidan untuk lebih meningkatkan ketrampilan yang dimiliki dan pengetahuan tentang ruptur perinium agar mengurangi terjadinya ruptur perinium tersebut, selain itu agar dapat dipertahankan dan lebih ditingkatkan lagi media informasi melalui buku panduan, leflet yang bisa dimanfaatkan oleh masyarakat banyak.

\section{DAFTAR PUSTAKA}

1. Winkjosastro, Hanifa. Ilmu kebidanan. Edisi tiga. Jakarta: YBP-SP; 2015.

2. Triana, Ani, dkk. Kegawatdaruratan Maternal dan Neonatal. Yogyakarta: Deepublish; 2015.

3. Saifudin, Abdul Bari. Buku Acuan Nasional Pelayanan Kesehatan Maternal Dan Neonatal. Jakarta : YBP-SP; 2011.

4. Rosdiana. Faktor-faktor yang mempengaruhi terjadinya ruptur perineum pada ibu bersalin normal di puskesmas PONED Darul Imarah Aceh. Jurnal: STIKes U' Budiyah. Banda Aceh; 2013.

5. Manuaba. Ilmu Kebidanan, Penyakit Kandungan dan Keluarga Berencana Untuk Pendidikan Bidan. Jakarta : EGC; 2011

6. Departemen Kesehatan RI. Asuhan persalinan Normal. Jakarta: JNPK-KR; 2008

7. Varney, Helen. Buku Ajar Asuhan Kebidanan. Edisi Empat, Jakarta: EGC; 2011.

8. Wirakusumah, Firman F. Obstetri fisiologi. Jakarta : EGC; 2011

9. Lontaan, Anita,dkk. Faktor - faktor yang berhubungan dengan robekan jalan lahir. Jurnal Ilmiah Kebidanan; 2015 